\title{
Examining Illiberal Trends and Anti-EU Politics in East Central Europe from a Domestic Perspective: State of Research and Outline of the Book
}

Lisa H. Anders and Astrid Lorenz

\section{INTRODUCTION}

In East Central Europe (ECE), democracy and the rule of law are under siege, most notably in Hungary and Poland and, to a lesser extent, also in the Czech Republic and Slovakia. Elected majorities weakened the judiciary, limited minority rights and curtailed activities of independent media and several NGOs. As a result of these illiberal trends, some of the former democratisation and Europeanisation frontrunners are now regarded as prime examples of democratic backsliding. EU actors repeatedly demanded to uphold EU foundational principles as enshrined in Article 2 of the Treaty on European Union (TEU). But the more they did

L. H. Anders $(\bowtie) \cdot$ A. Lorenz

Institute of Political Science, Leipzig University, Leipzig, Germany e-mail: 1.anders@uni-leipzig.de
A. Lorenz
e-mail: astrid.lorenz@uni-leipzig.de

(C) The Author(s) 2021

A. Lorenz and L. H. Anders (eds.), Illiberal Trends and Anti-EU Politics in East Central Europe, Palgrave Studies in European Union Politics, https://doi.org/10.1007/978-3-030-54674-8_1 
so, the more ECE governments reacted by accusing the EU of applying ill-defined rule of law concepts, by insisting on national sovereignty stipulated in Article 4(2) TEU and by emphasising the cultural differences between Eastern and Western Europe.

Relations between Brussels on the one hand and Budapest, Warsaw, Prague and Bratislava on the other hand further deteriorated during the so-called refugee crisis. The Visegrád countries openly opposed commonly agreed EU law, namely the refugee relocation scheme. When EU actors demanded compliance, ECE politicians argued that they had to defend their electorate. They fiercely refused to comply and complemented their opposition with an increasingly harsh anti-EU rhetoric. As a result, opposition against particular EU policies turned into general EU criticism- a development we subsume under the keyword of anti-EU politics.

As is also reflected in recent European case law, such problems and conflicts undermine the EU's legal system and previous integration achievements. In 2018, the Court of Justice of the European Union (CJEU) noted that European values and norms, particularly the fundamental right to an independent tribunal, can no longer be taken for granted in all EU member states. Referring to a Polish national, the CJEU ruled that judicial authorities in EU member states can now block the execution of a European arrest warrant if they consider that the independence of the judiciary in the issuing member state is no longer guaranteed (CJEU 2018). In 2020, a German Higher Regional Court refused for the first time to extradite a Polish suspect to his home country due to "profound doubts about the future independence of the Polish judiciary" (Bauomy 2020).

Illiberal trends and anti-EU politics have the potential to undermine mutual trust among member states and to alter relations between the EU and some of its member states permanently, as well as shattering established theorising in EU studies. Hence, it is crucial to understand their domestic causes, context conditions, processes and consequences. This edited volume, therefore, aims to provide in-depth empirical knowledge of the background of rule of law problems and the open defiance of EU rules in ECE countries. To arrive at a more encompassing understanding of these phenomena, it brings together researchers from different disciplines and with different theoretical perspectives on the illiberal trends and anti-EU politics in ECE countries. It contains qualitative case studies, comparative works and quantitative analyses of the societal, political and 
institutional processes. Together, the studies capture the different facets of the illiberal trends and anti-EU politics which is urgently needed for empirically informed theory-building. In doing so, they contribute to deepening the much-needed area expertise concerning Eastern and Central Europe (Dale et al. 2016) and help to explore if the differences between the East and the West are as sharp as often claimed by politicians.

\section{Illiberal Trends and the ECE Countries' Relations With Brussels}

It seems that around the globe, illiberalism is on the rise (Levitsky and Ziblatt 2018; Mounk 2018). Illiberalism can be defined as the rejection of mechanisms and institutions to protect individual rights and freedoms from those in power. In many Western democracies, the protection of individual rights and freedoms preceded democratisation and later was integrated into concepts of democracy (Zakaria 1997). Therefore, liberal democracy - a combination of the constitutionalist and the electoral principle-was long regarded as the standard model of democracy (Murphy 1993). However, these principles do not necessarily go hand in hand. As Fareed Zakaria put in his seminal article on illiberalism: "Democracy is flourishing; constitutional liberalism is not (...) Just as nations across the world have become comfortable with many variations of capitalism, they could well adopt and sustain varied forms of democracy" (1997, p. 23f). What we see today is that even established democracies can fall short of liberal norms.

Illiberal trends frequently manifest themselves along two dimensions: first, the dismantling of the political institutions guaranteeing checks and balances and minority rights. Often this happens "through a discontinuous series of incremental actions" (Waldner and Lust 2018, p. 95) when democratically elected authorities start to "systematically weaken, annihilate or capture internal checks on power" (Pech and Scheppele 2017, p. 10). As in most of the cases they do so by legal means, the current illiberal trends have also been described as "gradual setbacks under a legal façade" (Lührmann and Lindberg 2019). Secondly, the dismantling of counter-majoritarian institutions is frequently accompanied by a contestation of liberal social and cultural norms, i.e. the rejection of pluralism and an increasing mobilisation along the social-cultural axis of political contestation (Havlík 2019; Vachudova 2019). Along these lines, Kaczyński and Orbán promote their "cultural counter-revolution" (Krekó and Enyedi 
2018 , p. 45) which centres around cultural conservatism, Christianity and ethnic nationalism.

In all ECE countries, there are more or less manifest illiberal tendencies undermining the EU's foundational principles, though their particular form and extent are far from being uniform. When the Fidesz-KDNP party alliance won a two-thirds majority in the Hungarian parliament in 2010 , it named the elections a "revolution at the ballot box", mandating the new government to overhaul the constitutional order of the country. Since then, it has exploited its legislative dominance to undermine the independence of the judiciary, curbed the media and increasingly suppressed civil society actors (Bánkuti et al. 2012; Batory 2015; Priebus 2016; Scheppele 2013, 2015). As the Prime Minister explicitly stated in 2014, he aims to establish a new illiberal state (Orbán 2014) and he wants to break with the "dogmas" that have been adopted by the West as this will secure Christian values, cultural conservatism and a true Hungarian way of governing.

The Polish Law and Justice Party (PiS) had already started promoting in the early 2000s the idea of a "new and virtuous Fourth Republic" (Halmai 2017, p. 8). According to this idea, a radically new illiberal, centralised system based on a particular "moral order" should help to realise the aims of the "unfinished 1989 revolution" and overcome the alleged pathologies of the existing system. To realise this goal, PiS-in office since 2015-has weakened the Constitutional Tribunal and eroded various political and individual rights, such as the right to assembly and privacy (Sadurski 2018, 2019a).

Compared to these two cases, the Czech Republic currently undergoes "a quieter politics of backsliding" (Hanley and Vachudova 2018, p. 278; see also Lorenz 2020). Recent developments might nevertheless be "just as consequential in the longer term" (Buštíková and Guasti 2019, p. 322). The country's party system had more or less collapsed when Prime Minister Babiš-a technocratic populist-came to power with his slogan to run the state like a firm (Babiš 2017, p. 128 ff.). To increase the state's "efficiency", he suggested abolishing the senate and the regions, to downsize the parliament, to reduce the number of ministries and to strengthen the state's influence on public media (Havlík 2019). To date, however, there "has been no sustained, successful power grab" (Dawson and Hanley 2019, p. 716).

In Slovakia, the populist governing party SMER has deployed illiberal means since 2006. It repeatedly articulated anti-minority and anti-EU 
positions while the judiciary "continued to experience troubling government influence" (Freedom House 2018, see also Láštic 2019). Overall, however, corruption seems a bigger problem than illiberalism (Freedom House 2019). In 2018, the murder of a journalist and his fiancé caused large-scale anti-corruption protests and public demands to break with the established politicians. As a result, SMER leader Robert Fico resigned as Prime Minister. In 2020, the party OL'aNO (Ordinary People and Independent Personalities) won the national elections with an anti-crime campaign, but the fragmented parliament makes it complicated to form a coherent coalition and to find a clear political course.

The illiberal trends caused heated debates about the rule of law. Relations between Brussels and the Visegrád group-especially Budapest and Warsaw-have become strained and much more complicated. EU actors identified a "true rule of law crisis" (Reding 2013) and a "clear risk of a serious breach of the rule of law" in the ECE countries (European Commission 2019; Sargentini Report 2018), while many ECE politicians insisted on the concept of constitutional pluralism and presented themselves as "the true guardians of EU values" (Mos 2020, p. 13).

The second bone of contention is the asylum policy. The Visegrád countries vehemently opposed the refugee relocation scheme, openly defied European rules and court decisions in this policy field and, in doing so, questioned the principle of precedence of EU law over national law. Often politicians in these four countries justified their opposition with their more or less open rejection of Islam (Gotev 2015; Orbán 2015). Moreover, they actively engaged in anti-EU campaigns. The Hungarian government launched a "Let's Stop Brussels!" consultation in 2016 (Halmai 2016). The following year, it invested millions in billboards, leaflets, TV commercials, and mass mailings to spread its anti-immigrant appeals and to demonise Brussels (Krekó and Enyedi 2018, p. 45). Similarly, Czech politicians criticised "the Brussels dictatorship", echoing the well-known phrase of the former "Moscow dictatorship" (Jelínková 2019). Also, the Polish government regularly railed against the EU's intrusion into national affairs. These developments caused heated debates among EU member states about European burden-sharing, and ECE countries were repeatedly accused of lacking solidarity.

It is puzzling how the people in ECE perceive the illiberal trends and anti-EU politics. As Fig. I shows, in the last few years, trust in national government has grown in most countries, especially in Hungary and Poland, but remarkably in the Czech Republic as well. At the same time, 


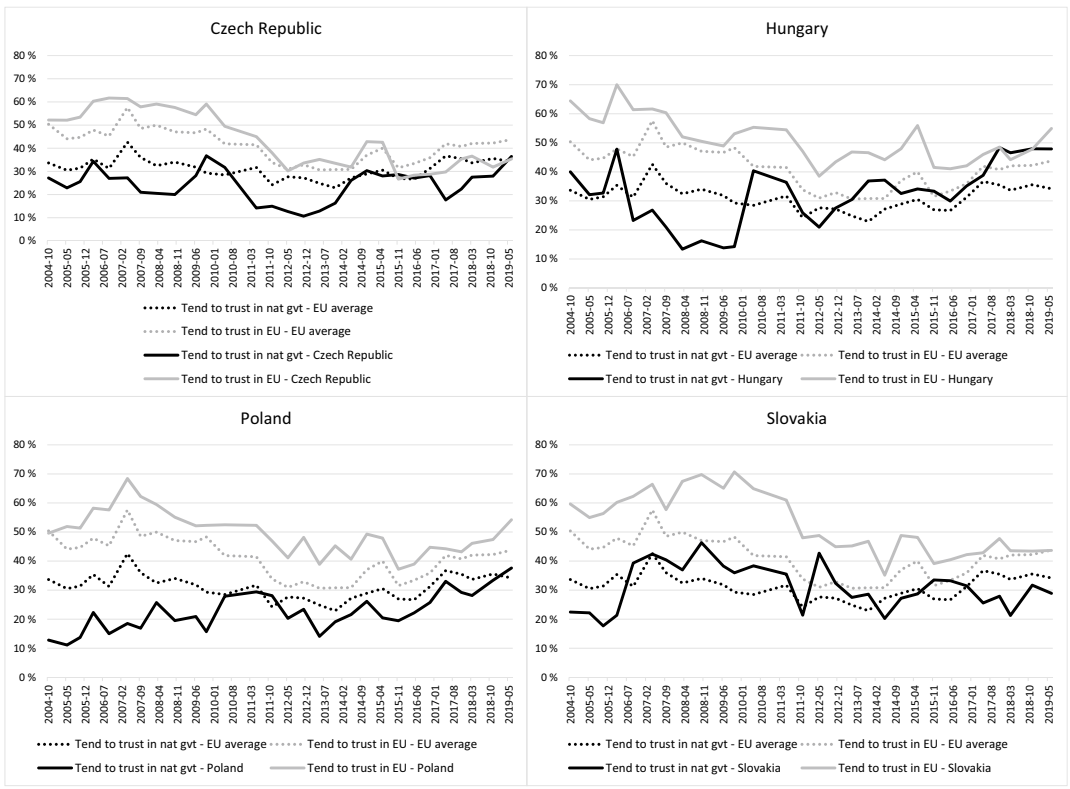

Fig. 1 Trust in national government and in the EU, 2004-2019 (Source Eurobarometer; Question wording: I would like to ask you a question about how much trust you have in certain media and institutions. For each of the following media and institutions, please tell me if you tend to trust it or tend not to trust it. The [NATIONALITY] government; The European Union)

the public's trust in the EU increased, although governments have intensified their anti-EU rhetoric and disregard European law where it collides with their domestic political agenda.

Past elections as well as opinion polls in Hungary have repeatedly shown that a majority of the population supports the government's agenda. . Despite Orbán's decidedly critical stance towards "Brussels" and the frequent clashes between Brussels and Budapest, Hungarians also show high trust in the EU. The same holds for Poland, where the

${ }^{1}$ Of course, this has to be interpreted in light of the amendments of the electoral system in the run-up to the parliamentary elections in 2014 (Krekó and Enyedi 2018, p. 42; OSCE 2014) and the revision of the media law (Polyák 2015) resulting in the dominance of pro-government media outlets (Freedom House 2020). 
governing PiS party could increase its vote share in the 2019 elections. Irrespective of the recent standoffs between Brussels and Warsaw, Polish people show high levels of trust in the EU. Czech people, in contrast, show comparatively low levels of trust in the EU, while the Czech government harshly criticised the relocation scheme but refrained from general anti-EU politics. In Slovakia, the past government's rhetoric and action vis-à-vis the EU was volatile (Baboš and Malová 2018) and the people are split in their trust in the EU, making Slovakia rank between Poland and the Czech Republic. Obviously, the illiberal trends and anti-EU politics in ECE are not uniform and the interrelationship between domestic politics and EU perceptions are not straightforward, calling for further exploration.

\section{Conflicts of a New Quality}

Clearly, conflicts between the EU and its member states on certain policies have existed ever since the Union and its predecessors were founded. EU and ECE actors already struggled over liberal rights and policies before what is now interpreted as an "illiberal turn". In the pre-accession period, the conflicts concerned ethnic minority rights, especially the rights of the Roma minority. Policy conflicts on environmental standards, military policy and the relations to Russia have also put strain on the relations between the EU and the ECE countries. But in general, the Visegrád countries were exceptionally good formal compliers (Dimitrova 2010; Treib 2014). Dissatisfaction with EU norms resulted in shallow transposition and "dead letters" rather than in open and intentional EU rule violation.

For various reasons, however, the recent disagreements between Brussels and ECE capitals present conflicts of a new quality. Firstly, they constitute very general polity disputes touching upon the meaning of democracy and rule of law. Now, the member states do not just bring diverging policy-preferences to the EU negotiation table but "also demand to decouple EU membership from the values and the processes of liberal democracy" (Vachudova 2019, p. 702). In this vein, the Hungarian Minister of Justice recently stressed that the rule of law "lacks welldefined rules". She further demanded that the "Union shall respect the national identities" and "not try to impose an artificial, one-size-fits-all framework" (Varga 2019). Similarly, the former Fidesz MEP and Jean Monnet Professor of Politics at the University College London, György 
Schöpflin (2015), argued that the rejection of liberal universalism does not contradict the application of the rule of law. As has been underlined, this disagreement about EU foundational values severely threatens the EU's core identity and has the potential to seriously endanger the Union's cohesion (Kelemen and Blauberger 2016, p. 321; Ovádek 2018, p. 495).

Secondly, these conflicts start to undermine existing modes of integration and Europeanisation. The refusal to take part in the relocation scheme was not just an ordinary case of non-compliance caused by lacking compliance capacities. ECE politicians generally criticised how decisions had been made and self-confidently argued that they had to defend their electorates' interests and values against illegitimate interference from the EU (Krastev 2017; Schlipphak and Treib 2016). Refusing to implement commonly agreed European laws and even ignoring CJEU rulings, they challenged - and still challenge - a central principle of European unification, namely integration through law. On the one hand, this principle requires national decision-makers to act as agents of Europeanisation. They need to accept and implement EU law faithfully (Bieber and Maiani 2014; Manko 2017; Radaelli 2003). On the other hand, this principle also entails the evolution of European law by case law of the Court of Justice of the EU and national courts. Both principles are increasingly challenged by ECE politicians. Especially as the European case law is regarded as undemocratic because the European court and national courts are not elected by the people.

Thirdly, the EU's instruments against illiberal backsliding and open non-compliance have proven more or less ineffective and prospects for swift solutions of the current conflicts seem poor. In view of the institutional reforms in Hungary and Poland, the European Commission first reacted with diplomatic instruments, later with harsh criticism, several infringement proceedings, the creation of a new Rule of law framework and the activation of its means of last resort, the Article 7 TEU procedure. Up until now, however, all these measures have not stopped backsliding. On the contrary, new conflicts emerged. Recent cases in point are the conflicts regarding the Polish law on the Supreme Court (European Commission 2018), the Hungarian law on foreign-funded NGOs (European Commission 2017) and the Hungarian laws that criminalise activities in support of asylum seekers. Against this backdrop, the European Parliament concluded that "the situation in both Poland and Hungary has deteriorated since the triggering of Article 7" (European Parliament 2020). 
Fourthly, the conflicts relating to the European asylum policy as well as conflicts on the rule of law created new alliances. While not all ECE governments were in direct trouble with the EU, many politicians are nevertheless willing to support those opposing EU directives and foundational principles. This is exemplified by the re-strengthening of the Visegrád group and its collective insistence on EU member states' right "to carry out domestic reforms within their competences" (Visegrad Group 2018). It is also reflected in the Hungarian and Polish governments' announcements to torpedo the Article 7 proceedings by vetoing any EU sanctions against these two member states. Due to these new alliances, ECE countries are often perceived as a homogenous region. Some scholars even identified the return of an East-West divide (Krastev 2017) as well as a "core-periphery divide" caused by the "ECE divergence from EU mainstream" (Ágh 2018). Adding to this impression, ECE politicians repeatedly stressed the cultural differences between the East and the West.

Finally, as has been shown in the previous section, significant parts of the ECE societies support both European integration and their governments. Many citizens, while generally welcoming European integration and trusting EU institutions, can be mobilised by the idea of pursuing an inherently national way of "doing things" instead of continuing the former strategy of importing what seems to them to be Western European democracy and policy templates. Obviously, they support their governments' illiberal agendas.

\section{State of Research}

The illiberal trends and anti-EU politics came as a surprise not only for politicians, but also for many EU and democratisation scholars. Most of them deemed the EU's 2004 eastern enlargement as a success story, as particularly in Hungary, Poland, Slovakia and Czechia, Europeanisation and democratisation seemed to reinforce each other. The EU had governed its enlargement by means of conditionality (Schimmelfennig and Sedelmeier 2004) and the candidate countries' ruling elites were more than willing to fulfil the Copenhagen criteria as they "overlapped with their political and economic agendas" (Vachudova 2005, p. 78). After their accession, ECE countries were quickly regarded as more or less robust and consolidated democracies (see, for instance, reports by Freedom House, Rupnik and Zielonka 2013, p. 3). 
Most democratisation and EU scholars expected ECE countries to be immune to democratic backsliding (Merkel 2010), and they predominantly attributed this to the EU's conditionality policy (Dawson and Hanley 2019, p. 711). Already prior to the EU accession, scholars had expected EU membership to generate "powerful, broad-based and longterm support for the establishment of democratic institutions because it is irreversible, and sets in train a cumulative process of economic and political integration that offers incentives and reassurances to a very wide array of social forces" (Whitehead 1996, 19). This expectation also guided actors in ECE countries, like Poland (Sadurski 2004). After the EU enlargement in 2004, scholars agreed that EU conditionality had a decisive "transformative power" (Grabbe 2006) and helped "postcommunist countries [to] consolidate their democracies" (Dimitrova and Pridham 2004, p. 93 f). In the same vein, later publications highlighted that a lock-in of pre-accession institutional changes would contribute to their persistence even after accession when the EU's sanctioning power weakened (Sedelmeier 2012).

Surely enough, there were also critical voices. Early on, observers noted low participation rates and a radicalisation of the remaining active electorate in Eastern Europe. They warned not "to paint an overly optimistic picture of the future that lies before the democracies of Central and Eastern Europe" (Greskovits 2007, p. 46). Yet, such concerns were hardly heard but "swept away by EU euphoria and over-optimism that EU membership with all its 'automatic' effects would resolve the basic contradictions between and within economic, political and social developments" (Ágh 2016, p. 12).

Meanwhile, it became clear that the standard assumption of a more or less linear Europeanisation and democratic consolidation was too optimistic. It obviously needs revision. Political systems are still in flux after 30 years of democratisation and Europeanisation before and after the formal accession (cf. Guasti and Mansfeldová 2018). These dynamics attracted the attention of various scholars. Broadly speaking, the expanding body of literature on current developments in ECE falls into three categories. First, case studies on backsliding dynamics in specific countries. Secondly, preliminary works on the potential causes of backsliding. Thirdly, contributions discussing possible remedies against illiberal backsliding.

Numerous case studies trace the institutional reforms dismantling the rule of law in ECE countries (Batory 2015; Jaremba 2016; Priebus 2016; 
Rupnik 2012; Sadurski 2019a, 2019b; Sólyom 2015). To describe the phenomenon of interest, they came up with an astonishing variety of keywords, such as "Frankenstate" (Scheppele 2013), "diffusely defective democracy" (Bogaards 2018), "Potemkin democracy" or "elected autocracy" (Ágh 2015) and "externally constrained hybrid regime" (Bozóki and Hegedús 2018). More recent studies also analyse in greater detail the ideational foundations of the illiberal backlash in ECE countries as well as the rhetoric of the illiberal agents (Buzogány and Varga, 2018; Dawson and Hanley 2019; Mos 2020). A few exceptions aside, these studies focus disproportionally on the most visible cases of backsliding: Hungary and Poland (Cianetti et al. 2018). They certainly provide an enlightening take on backsliding dynamics and the associated institutional changes in these two paradigmatic cases. The domestic roots of backsliding and current conflicts between the EU and ECE countries as well as alternative problem perceptions within these countries, however, have received comparatively little attention so far.

A second strand of the literature addresses the potential causes of the illiberal backlash. These studies approach the phenomenon of interest from various theoretical viewpoints, including political economy theories, agent-based or institutionalist approaches or theories of political culture. They explain the erosion of democracy by economic and financial problems (Szente 2017, p. 472), by demographic developments (Krastev 2018) or by stressing the role of actors and their discourses in making and unmaking democratic institutions (Dawson and Hanley 2019). Some trace it back to the post-1989 dominance of the "liberal orthodoxy", stressing that post-communist countries were expected to "return to Europe" mainly by mimicking Western liberal democratic blueprints (Krastev and Holmes 2020). Others highlight that pre-accession conditionality merely resulted in formal and rather shallow "conditionality constitutionalism", underlining that constitutionalism and the rule of law still lack "a firm social and politico-cultural entrenchment in civil and political society" (Blokker 2016, p. 250; see also Pridham 2005). In this perspective, the PiS victory has shown that ECE societies have remained nationalist and have "merely been pretending to accept the shared norms of liberal democracy, only to reap the economic and financial fruits of their EU membership" (Karolewski and Benedikter 2017, p. 519). This variety of approaches shows that we are still missing a strong and widely acknowledged explanation of the illiberal trends. As a recent review aptly concluded, there is no "readily available set of theories that we (...) can 
uncontroversially adopt, adapt, and apply to the problem of backsliding" (Waldner and Lust 2018, p. 106; also compare Cianetti et al. 2018, p. 243).

A third strand of the literature explores how the EU can enforce its foundational values. Ample studies analyse the deployment and actual effects of the EU's various instruments to counter rule of law backsliding in its member states. They focus on political instruments, such as the Article 7 procedure, which can ultimately result in the suspension of the backsliding government's voting rights, the Rule of law framework established in 2014 and the Rule of law dialogue, launched in the same year by the Council of the EU (Closa 2016, 2018; Kochenov et al. 2017; Kochenov and Pech 2015, 2016; Müller 2015; Oliver and Stefanelli 2016). Furthermore, they examine the effects of judicial tools against backsliding, such as infringement proceedings and private enforcement litigation in national courts (Blauberger and Kelemen 2016; De Schutter 2017). Most of these studies approach the ECE countries from an enforcement and top-down perspective, and they agree that political and judicial instruments have proven rather ineffective. Thus, some recent publications discuss if existing instruments could and should be employed differently (Pech and Kochenov 2019). Other works address the suitability of new oversight instruments, such as the conditionality of EU funds (Blauberger and van Hüllen 2020; Neuwahl and Kovacs 2020; Pech and Scheppele 2017).

Publications on the EU's instruments against democratic backsliding are predominantly written by legal scholars (Ovádek 2018, p. 499). Against this backdrop, it comes as no surprise that they focus on legal aspects and legalistic remedies for the erosion of the rule of law while the social, political and cultural preconditions of the rule of law have remained largely neglected (Blokker 2016). Experiences with ECE countries, however, clearly demonstrate that democracy does not rest on law alone. It needs to be supported by decision-makers and rooted in a society which perceives it as legitimate. As Pridham (2005) and Blokker (2016) and others argued, societal attitudes were much less influenced by EU conditionality politics than the domestic legal framework. Nevertheless, they are often ignored by de-democratisation and Europeanisation studies as well as by legal analyses of rule of law problems inside the EU. Accordingly, some scholars criticise the EU's assumption that liberal democracy and compliance within the member states can be secured by law or legalistic instruments, and that the European constitutionalism rests upon a 
set of values shared within the member states (Dupré 2015). In this vein, recent publications called for broadening the one-sided focus on formal institutions and legal solutions and to examine empirically "the political and socio-economic factors which enable democratic deficits to take root" (Ovádek 2018, p. 501, see also Blokker 2016, p. 266; Cianetti et al. 2018).

\section{Aims ANd Outline of THE Book}

This volume aims to map and to understand illiberal trends and anti-EU politics in East Central Europe by linking EU studies with area expertise and assembling contributions from different disciplines. Empirically, it adds to the literature by zooming into domestic processes in all four countries of the region. Examining rule of law and compliance challenges in Slovakia and the Czech Republic as well allows us to compare and contrast the dynamics in Hungary and Poland. Several contributions also broaden the perspective comparing ECE countries with other EU states, thereby testing whether differences between the Visegrád countries and the remaining EU member states are really as pronounced as frequently claimed.

The volume adds to theory-building by exploring how different theoretical perspectives can help to capture the domestic context conditions, processes and consequences of the illiberal trends and anti-EU politics in ECE. Individual contributions are not bound to a specific theoretical perspective. This is not only due to the fact that a generally accepted theoretical model for these phenomena is still missing. More importantly, we are convinced that complex problems need complex analytical approaches as well as area-sensitive solutions. We therefore bring together complementary analytical approaches from sociology, political and legal science. This diversity helps to arrive at a more encompassing understanding of the current developments in ECE countries and contributes to moving beyond a mainly legalistic or institution-centred perspective on backsliding and the EU's instruments against it.

The different theoretical perspectives aside, the contributions are connected by a number of shared assumptions. First, they model politics as a process. Secondly, they focus on individual or collective actors' perceptions, rhetoric, actions and interactions. Thirdly, though focusing on actors as drivers and shapers of policies, they conceive them as embedded in a given context. The contributions share the premise that the context 
influences-but does not determine-the actors' strategies. Therefore, similar institutions (like democratic or EU norms) and legal instruments neither have to be perceived in the same way nor yield similar effects. Fourthly, many of the contributions interpret illiberal trends and anti-EU politics as causally entangled phenomena which sometimes are not selfstanding policy aims but rather instruments or effects of actors' strategies to reach their actual goal.

These shared basic assumptions guide the overall structure of the book. Following a classic processual input-output model of democracy (Easton), it starts from society and analyses citizens' perceptions and demands in part 1. Part 2 then looks at how political actors respond to these inputs and strive to shape societal demands through their rhetoric and campaigns. Along these lines, contributions also analyse if actors follow a coherent illiberal or anti-EU ideology and uncover how they struggle to realise certain policies inside the government system and with societal actors. Part 3 illuminates how and why the policy output-illiberal reforms and non-compliance with EU rules-causes conflicts with European actors. It also investigates EU actors' strategies to secure EU norms against illiberal backsliding as well as the counter-strategies this has brought about in ECE countries. The contributions of the concluding fourth part of the book discuss theoretical and conceptual implications for democracy, the rule of law and Europeanisation.

In detail, the book is structured as follows: As mentioned, the contributions to the opening part, including Chapters 2 through 4, focus on citizens' perceptions and demands. More specifically, the quantitative studies analyse the prevalence of Euroscepticism, the nexus between Euroscepticism and Islamophobia and conceptions of European solidarity in East Central European and the remaining member states. Together, they help to assess whether and how citizens' attitudes towards the EU and European integration in East Central Europe differ from other EU member states and if illiberal and anti-EU politics in ECE countries can be explained by these differences.

In Chapter 2, Lars Vogel examines if anti-EU politics in East Central European countries are backed by a particularly negative public opinion on European integration. To do so, he analyses if there are regional or EU-wide patterns, trends and determinants of Euroscepticism. He compares the explanatory power of classic Euroscepticism accounts and also explores if public opinion on European integration is linked to critical attitudes towards immigration and illiberal conceptions of democracy. 
Gert Pickel and Cemal Öztürk then analyse in Chapter 3 why especially the issues of asylum and migration have led to such vehement opposition from the Visegrád states. Taken together, Chapters 2 and 3 demonstrate that anti-EU politics of ECE countries cannot simply be attributed to high levels of Euroscepticism in the region. Rather, they result from the rejection of specific EU policies. This finding is also supported in Chapter 4 by Florian K. Kley and Holger Lengfeld. To test if ECE countries generally show lower levels of European solidarity, as often argued during the refugee crisis, the authors explore solidarity in other policy areas. They comparatively investigate ECE citizens' willingness to support indebted countries financially and their attitudes towards EU-wide redistributive measures. Again, the contribution underlines that ECE countries are less distinct from the other EU countries than assumed in public and academic debate.

The second part, including Chapters 5 through 8, sheds light on political actors and their illiberal and anti-EU rhetoric and practice. Analysing politicians, parties, and administrations, the contributions complement existing studies on backsliding in ECE countries which typically focus on institutional changes as well as the general state of democracy and devoted less attention to the agents of the current illiberal trends. The comparative works and case studies reveal considerable intra-regional and temporal variations regarding the illiberal agendas of political actors. Furthermore, they demonstrate the differences between the illiberal or anti-EU rhetoric on the one hand and the actual policies on the other hand.

In Chapter 5, Vratislav Havlík and Vít Hloušek provide a comprehensive overview of all four countries of interest, comparing the illiberal ideology and practice of governing parties in the Czech Republic, Hungary, Poland and Slovakia. The authors show that not all decisionmakers in the region follow a coherent illiberal agenda and that illiberal practices vary as well. Differences between rhetoric and practice are also discussed in Chapter 6. Focusing on Hungary and the Czech Republic, Paula Beger analyses the link between the public contestation of the EU's asylum and migration policies and the member states' compliance in the policy field. Her contribution also provides an explanation why similar levels of public contestation in both countries resulted in a different compliance performance. Next, in Chapter 7, Michał Dulak looks more closely at the link between illiberal backsliding and anti-EU party rhetoric. To analyse this link, he explores over time how the main ruling and the 
main opposition party in Poland, $\mathrm{PO}$ and PiS, position themselves vis-àvis the EU and then checks whether this is backed by societal attitudes. In the last chapter of the second part, Petra Guasti sheds light on the antipluralist dimension of illiberalism, analysing how certain political actors in the Czech Republic and Slovakia block pro-universal rights legislation by the EU or the Council of Europe (Chapter 8). In line with Chapter 5, the contribution shows that illiberal backlashes are not necessarily the result of a coherent illiberal ideology, but also of short-term strategic considerations of political actors.

The third part of the volume, including Chapters 9 through 11, addresses the EU's political reactions to the illiberal turn and anti-EU politics in ECE countries. To contribute to current scholarly debates on the EU's oversight instruments, the authors go beyond a top-down enforcement perspective and pay particular attention to the interplay between EU and domestic actors. In doing so, they shed light on the deployment of the EU's remedies against rule of law backsliding and the counter-strategies they have caused. Furthermore, they address how the problems around the illiberal turn and anti-EU politics can be solved by non-legalistic means.

In Chapter 9, Attila Vincze critically reflects on misperceptions in current rule of law conflicts between Brussels and Budapest and their usage in domestic debates. His contribution helps to understand how and why governments criticised for illiberal practices can frame EU interventions such as the Article 7 procedure as political attacks. The same is true for Chapter 10 by Lisa H. Anders and Sonja Priebus, who analyse how the Commission justified rule of law-related infringement procedures against Hungary and how the Fidesz government reacted legally and rhetorically. Given the apparent shortcomings of the EU's instruments, Claudia Y. Matthes then investigates in Chapter 11 how domestic civil rights movements can contribute to safeguarding the rule of law in a bottom-up manner. Focusing on the Polish case, she illustrates how and by which means civil society organisations can keep the issue of backsliding on the domestic and European political agenda.

The three contributions of the concluding fourth part of the book discuss conceptual and theoretical implications for future research. They add to EU studies by moving beyond ECE and a narrow EU perspective and embedding the empirical observations into broader theoretical reflections on democracy and rule of law. In Chapter 12, Luca Tomini and Seda Gürkan elaborate on how illiberal trends and autocratisation 
are related to anti-EU-politics and de-Europeanisation. Ireneusz Paweł Karolewski argues in Chapter 13 for a general theory of democratic backsliding, stressing that it should cover societal, institutional and processual aspects. In the final chapter, Chapter 14, Astrid Lorenz and Lisa $\mathrm{H}$. Anders highlight the added value of the volume by summarising how the main findings of the individual chapters speak to each other and jointly provide a comprehensive picture of illiberal trends and anti-EU politics in ECE. Moreover, they link the findings to the state of research and discuss theoretical implications as well as potential avenues for future research.

Overall, the contributions provide rich empirical material to illuminate various facets of the illiberal trends and anti-EU politics in East Central Europe. They thereby contribute to filling a gap that has emerged due to the decline in regional and area studies in many EU member states since the 1990s. When referring to East Central Europe, EU scholars often have to rely on a small number of sources available in English and they all too often infer from the politicians' public rhetoric to their actual policies. As theory-building is also dependent on in-depth case knowledge, this will be provided by contributions of authors with the required language skills, along with the profound country, regional and theoretical expertise.

To be clear, the regional focus of the book neither implies that illiberal trends and anti-EU politics are limited to this region nor that they are equally manifest in all four East Central European countries. Illiberal rhetoric and action, critical discourses on the EU in general and joint decision-making in particular, as well as the renewed interest in national solutions are not confined to the region. Thus, the findings will be of interest not only to experts on East Central European countries, but also to those studying the rule of law, illiberal backsliding and the EU's instruments against it. They will also broaden the empirical knowledge of all those interested in European integration and the interplay between the European and the domestic level.

\section{References}

Ágh, Attila. 2015. De-Europeanization and De-Democratization Trends in ECE: From the Potemkin Democracy to the Elected Autocracy in Hungary. Journal of Comparative Politics 8 (2): 4-26.

Ágh, Attila. 2016. The Deconsolidation of Democracy in East-Central Europe: The New World Order and the EU's Geopolitical Crisis. Politics in Central Europe 12 (3): 1-35. 
Ágh, Attila. 2018. Decline of Democracy in the ECE and the Core-Periphery Divide: Rule of Law Conflicts of Poland and Hungary with the EU. Journal of Comparative Politics 11 (2): 30-48.

Babiš, Andrej. 2017. O čem snim, když náhodou spim. Vize roku 2035 pro Českou republiku, pro naše déti. Prague.

Baboš, P., and D. Malová. 2018. Slovakia: Political Development and Data for 2017. European Journal of Political Research Political Data Yearbook 57 (1): $255-261$.

Bánkuti, M., G. Halmai, and K.L. Scheppele. 2012. From Separation of Powers to a Government without Checks: Hungary's Old and New Constitutions. In Constitution for a Disunited Nation: On Hungary's 2011 Fundamental Law, ed. Gábor A. Tóth, 237-268. Budapest: Central European University Press.

Batory, Agnes. 2015. Populists in Government? Hungary's "System of National Cooperation". Democratization 23 (2): 283-303.

Bauomy, Jasmin. 2020. Germany Refuses to Extradite Pole Under European Arrest Warrant Due to Fair Trial Fears. Euronews. https://www.euronews. com/2020/03/09/germany-refuses-to-extradite-pole-under-european-arr est-warrant-due-to-fair-trial-fears. Accessed 4 May 2020.

Bieber, R., and F. Maiani. 2014. Enhancing Centralized Enforcement of EU Law: Pandora's Toolbox? Common Market Law Review 51 (4): 1057-1092.

Blauberger, M., and R.D. Kelemen. 2016. Can Courts Rescue National Democracy? Judicial Safeguards Against Democratic Backsliding in the EU. Journal of European Public Policy 24 (3): 321-336.

Blauberger, M., and V. van Hüllen. 2020. Conditionality of EU Funds: An Instrument to Enforce EU Fundamental Values? Journal of European Integration, 1-16. https://doi.org/10.1080/07036337.2019.1708337.

Blokker, Paul. 2016. EU Democratic Oversight and Domestic Deviation from the Rule of Law. Sociological Reflections. In Reinforcing rule of law oversight in the European Union, ed. C. Closa and D. Kochenov, 249-269. Cambridge: Cambridge University Press.

Bogaards, Matthijs. 2018. De-democratization in Hungary: Diffusely Defective Democracy. Democratization 25 (8): 1481-1499.

Bozóki, A., and D. Hegedús. 2018. An Externally Constrained Hybrid Regime: Hungary in the European Union. Democratization 4 (2): 1173-1189.

Buštíková, L., and P. Guasti. 2019. The State as a Firm: Understanding the Autocratic Roots of Technocratic Populism. East European Politics and Societies: and Cultures 33 (2): 302-330.

Buzogány, A., and M. Varga. 2018. The Ideational Foundations of the Illiberal Backlash in Central and Eastern Europe: The Case of Hungary. Review of International Political Economy 25 (6): 811-828. 
Cianetti, L., J. Dawson, and S. Hanley. 2018. Rethinking "Democratic Backsliding" in Central and Eastern Europe-Looking Beyond Hungary and Poland. East European Politics 34 (3): 243-256.

CJEU. 2018. Judgment in Case C-216/18 PPU: Press Release No113/18. https://curia.europa.eu/jcms/upload/docs/application/pdf/2018-07/cpl 80113en.pdf. Accessed 4 May 2020.

Closa, Carlos. 2016. Reinforcing EU Monitoring of the Rule of Law. Normative Arguments, Institutional Proposals and the Procedural Limitations. In Reinforcing Rule of Law Oversight in the European Union, ed. C. Closa and D. Kochenov, 15-35. Cambridge: Cambridge University Press.

Closa, Carlos. 2018. The Politics of Guarding the Treaties: Commission Scrutiny of Rule of Law Compliance. Journal of European Public Policy 51: 1-21.

Dale, G., K. Miklóssy, and D. Segert (eds.). 2016. The Politics of East European Area Studies. London and New York: Routledge.

Dawson, J., and S. Hanley. 2019. Foreground Liberalism, Background Nationalism: A Discursive-institutionalist Account of EU Leverage and 'Democratic Backsliding' in East Central Europe. Journal of Common Market Studies 57 (4): 710-728.

De Schutter, Olivier. 2017. Infringement Proceedings as a Tool for the Enforcement of Fundamental Rights in the European Union: Report commissioned by the Open Society European Policy Institute. https://www.opensocietyfoundat ions.org/uploads/f637765b-ee20-4e6e-9cda-b74151f9a369/infringementproceedings-as-tool-for-enforcement-of-fundamental-rights-in-eu-20171214. pdf. Accessed 4 May 2020.

Dimitrova, Antoaneta L. 2010. The New Member States of the EU in the Aftermath of Enlargement: Do New European Rules Remain Empty Shells? Journal of European Public Policy 17 (1): 137-148.

Dimitrova, A.L., and G. Pridham. 2004. International Actors and Democracy Promotion in Central and Eastern Europe: The Integration Model and Its Limits. Democratization 11 (5): 91-112.

Dupré, Catherine. 2015. The Unconstitutional Constitution: A Timely Concept. In Constitutional Crisis in the European Constitutional Area: Theory, Law and Politics in Hungary and Romania, ed. A. v. Bogdandy and P. Sonnevend, 364-383. Oxford and Portland: Nomos.

European Commission. 2017. European Commission Steps Up Infringement Against Hungary on NGO Law. http://europa.eu/rapid/press-release_IP17-3663_en.htm. Accessed 4 May 2020.

European Commission. 2018. Rule of Law: Commission Launches Infringement Procedure to Protect the Independence of the Polish Supreme Court. http://eur opa.eu/rapid/press-release_IP-18-4341_en.htm. Accessed 4 May 2020.

European Commission. 2019. Rule of Law: European Commission Launches Infringement Procedure to Protect Judges in Poland from Political Control. 
http://europa.eu/rapid/press-release_IP-19-1957_en.htm. Accessed 4 May 2020.

European Parliament. 2020. Rule of Law in Poland and Hungary Has Worsened: Press Release. https://www.europarl.europa.eu/news/en/press-room/202 00109IPR69907/rule-of-law-in-poland-and-hungary-has-worsened. Accessed 4 May 2020.

Freedom House. 2018. Nations in Transit 2018: Slovakia Country Profile. https://freedomhouse.org/report/nations-transit/2018/slovakia. Accessed 4 May 2020.

Freedom House. 2019. Slovakia. https://freedomhouse.org/country/slovakia/ freedom-world/2019. Accessed 4 May 2020.

Freedom House. 2020. Hungary. https://freedomhouse.org/country/hun gary/freedom-world/2020. Accessed 4 May 2020.

Gotev, Georgi. 2015. Commission Frowns on 'Christian Only' Solidarity with Migrants. https://www.euractiv.com/section/languages-culture/news/ commission-frowns-on-christian-only-solidarity-with-migrants/. Accessed 10 June 2010.

Grabbe, Heather. 2006. The EU's Transformative Power: Europeanization Through Conditionality in Central and Eastern Europe. Palgrave Studies in European Union Politics. London: Palgrave Macmillan.

Greskovits, Béla. 2007. Is East-Central Europe Backsliding? Economic Woes and Political Disaffection. Journal of Democracy 18 (4): 40-46.

Guasti, P., and Z. Mansfeldová (eds.). 2018. Democracy Under Stress. Changing Perspectives on Democracy, Governance and their Measurement. Prague: Institute of Sociology of the Academy of Sciences.

Halmai, Gábor. 2016. The Invalid Anti-Migrant Referendum in Hungary. https://verfassungsblog.de/hungarys-anti-european-immigration-laws/.

Accessed 4 May 2020.

Halmai, Gábor. 2017. Second-Grade Constitutionalism? The Case of Hungary and Poland. CSF-SSSUP WORKING PAPER SERIES (1).

Hanley, S., and M.A. Vachudova. 2018. Understanding the Illiberal Turn: Democratic Backsliding in the Czech Republic. East European Politics 34 (3): 276-296.

Havlík, Vlastimil. 2019. Technocratic Populism and Political Illiberalism in Central Europe. Problems of Post-Communism 66 (6): 369-384.

Jaremba, Urzula. 2016. The Rule of the Majority vs. the Rule of Law: How Poland Has Become the New Enfant Terrible of the European Union. Tijdschrift Voor Constitutioneel Recht 7 (3): 262-274.

Jelínková, Marie. 2019. A Refugee Crisis Without Refugees: Policy and Media Discourse on Refugees in the Czech Republic and Its Implications. Central European Journal of Public Policy 13 (1): 33-45. 
Karolewski, I.P., and R. Benedikter. 2017. Poland's Conservative Turn and the Role of the European Union. European Political Science 16 (4): 515-534.

Kelemen, R.D., and M. Blauberger. 2016. Introducing the Debate: European Union Safeguards Against Member States' Democratic Backsliding. Journal of European Public Policy 24 (3): 317-320.

Kochenov, D., L. Pech, and K.L. Scheppele. 2017. The European Commission's Activation of Article 7: Better Late than Never? https://verfassungsblog. de/the-european-commissions-activation-of-article-7-better-late-than-never/. Accessed 4 May 2020.

Kochenov, D., and L. Pech. 2015. Monitoring and Enforcement of the Rule of Law in the EU: Rhetoric and Reality. European Constitutional Law Review 11 (03): 512-540.

Kochenov, D., and L. Pech. 2016. Better Late Than Never? On the European Commission's Rule of Law Framework and Its First Activation. Journal of Common Market Studies 54 (5): 1062-1074.

Krastev, Ivan. 2017. The Refugee Crisis and the Return of the East-West Divide in Europe. Slavic Review 76 (2): 291-296.

Krastev, Ivan. 2018. Eastern Europe's Illiberal Revolution: The Long Road to Democratic Decline. Foreign Affairs 97 (3): 49-56.

Krastev, Ivan, and S. Holmes. 2020. The Light That Failed: A Reckoning. London: Penguin.

Krekó, P., and Z. Enyedi. 2018. Explaining Eastern Europe: Orbán's Laboratory of Illiberalism. Journal of Democracy 29 (3): 39-51.

Láštic, Erik. 2019. Slovakia: Political developments and data in 2018. European Journal of Political Research Political Data Yearbook 58 (1): 241-247.

Levitsky, Steven, and D. Ziblatt. 2018. How Democracies Die. New York: Crown. Lorenz, Astrid. 2020. The Puzzling Crisis of Democratisation in the Czech Republic. Towards More Case Knowledge and a Broader Perspective in Comparative Politics. In Czech Democracy in Crisis, ed. A. Lorenz and H. Formánková, 1-18. Cham: Palgrave Macmillan.

Lührmann, A., and S.I. Lindberg. 2019. A Third Wave of Autocratization Is Here: What Is New About It? Democratization 26 (7): 1095-1113.

Manko, Rafat. 2017. The EU as a Community of Law: Overview of the Rule of Law in the Union. European Parliament Research Service PE 599.364.

Merkel, Wolfgang. 2010. Plausible Theory, Unexpected Results: The Rapid Democratic Consolidation in Central and Eastern Europe. In Landmark 1989: Central and Eastern European societies twenty years after the system change, ed. H. Best and A. Wenninger, 7-26.

Mos, Martijn. 2020. Ambiguity and Interpretive Politics in the Crisis of European Values: Evidence from Hungary. East European Politics 36 (2): $1-21$. 
Mounk, Yasha. 2018. The People vs. Democracy: Why Our Freedom Is in Danger and How to Save It. Harvard: Harvard University Press.

Müller, Jan-Werner. 2015. Should the EU Protect Democracy and the Rule of Law inside Member States? European Law Journal 21 (2): 141-160.

Murphy, Walter F. 1993. Constitutions, Constitutionalism and Democracy. In Constitutionalism and Democracy: Transitions in the Contemporary World; the American Council of Learned Societies Comparative Constitutionalism Papers, ed. D. Greenberg, S.N. Katz, M.B. Oliviero, and S.C. Wheatley, 3-25. New York: Oxford University Press.

Neuwahl, N., and C. Kovacs. 2020. Hungary and the EU's Rule of Law Protection. Journal of European Integration, 1-16.

Oliver, P., and J. Stefanelli. 2016. Strengthening the Rule of Law in the EU: The Council's Inaction. Journal of Common Market Studies 54 (5): 1075-1084.

Orbán, Viktor. 2014. Full text of Viktor Orbán's speech at Băile Tusnad (Tusnádfürdö) of 26 July 2014. https://budapestbeacon.com/full-text-ofviktor-orbans-speech-at-baile-tusnad-tusnadfurdo-of-26-july-2014. Accessed 4 May 2020.

Orbán, Viktor. 2015. We Are Protecting Europe's Values. https://www.kor many.hu/en/the-prime-minister/news/we-are-protecting-europe-s-values.

Accessed 10 June 2020.

OSCE. 2014. Hungary Parliamentary Elections 6 April 2014: OSCE/ODIHR Limited Election Observation Mission Final Report. https://www.osce.org/ odihr/elections/hungary/121098?download=true. Accessed 4 May 2020.

Ovádek, Michal. 2018. The Rule of Law in the EU: Many Ways Forward But Only One Way to Stand Still? Journal of European Integration 40 (4): 495503.

Pech, L., and D. Kochenov. 2019. Strengthening the Rule of Law Within the European Union: Diagnoses, Recommendations, and What to Avoid: Policy Brief-June 2019. https://reconnect-europe.eu/wp-content/uploads/ 2019/06/RECONNECT-policy-brief-Pech-Kochenov-2019June-publish. pdf. Accessed 4 May 2020.

Pech, L., and K.L. Scheppele. 2017. Illiberalism Within: Rule of Law Backsliding in the EU. Cambridge Yearbook of European Legal Studies 19: 3-47.

Polyák, Gábor. 2015. Context, Rules and Praxis of the New Hungarian Media Laws: How does the Media Law Affect the Structure and Functioning of Publicity. In Constitutional Crisis in the European Constitutional Area: Theory, Law and Politics in Hungary and Romania, ed. A. v. Bogdandy and P. Sonnevend, 125-150. Baden-Baden: Nomos.

Pridham, Geoffrey. 2005. Designing Democracy: EU Enlargement and Regime Change in Post-Communist Europe. Cham: Palgrave Macmillan.

Priebus, Sonja. 2016. Hungary. In Constitutional Politics in Central and Eastern Europe, ed. A. Fruhstorfer and M. Hein, 101-143. Wiesbaden: Springer. 
Radaelli, Claudio M. 2003. The Europeanization of Public Policy. In The politics of Europeanization, ed. C.M. Radaelli and K. Featherstone, 27-56. New York: Oxford University Press.

Reding, Viviane. 2013. The EU and the Rule of Law-What Next? September 4. Brussels. http://europa.eu/rapid/press-release_SPEECH-13-677_de.htm. Accessed 4 May 2020.

Rupnik, Jacques. 2012. Hungary's Illiberal Turn: How Things Went Wrong. Journal of Democracy 23 (3): 132-137.

Rupnik, J., and J. Zielonka. 2013. Introduction: The State of Democracy 20 Years on. East European Politics and Societies and Cultures 27 (1): 3-25.

Sadurski, Wojciech. 2004. Accession's Democracy Dividend: The Impact of the EU Enlargement upon Democracy in the New Member States of Central and Eastern Europe. European Law Journal 10 (4): 371-401.

Sadurski, Wojciech. 2018. How Democracy Dies (in Poland): A Case Study of Anti-Constitutional Populist Backsliding. Sydney Law School Research Paper 18(01). Advance online publication.

Sadurski, Wojciech. 2019a. Poland's Constitutional Breakdown. Oxford Comparative Constitutionalism, 1st ed. Oxford: Oxford University Press.

Sadurski, Wojciech. 2019b. Polish Constitutional Tribunal Under PiS: From an Activist Court, to a Paralysed Tribunal, to a Governmental Enabler. Hague Journal on the Rule of Law 11 (1): 63-84.

Sargentini Report. 2018. Report on a Proposal Calling on the Council to Determine, Pursuant to Article 7(1) of the Treaty on European Union, the Existence of a Clear Risk of a Serious Breach by Hungary of the Values on Which the Union Is Founded. European Parliament. http://www.europarl.europa.eu/ doceo/document/A-8-2018-0250_EN.html. Accessed 4 May 2020.

Scheppele, Kim L. 2013. The Rule of Law and the Frankenstate: Why Governance Checklists Do Not Work. Governance 26 (4): 559-562.

Scheppele, Kim. L. 2015. Understanding Hungary's Constitutional Revolution. In Constitutional Crisis in the European Constitutional Area: Theory, Law and Politics in Hungary and Romania, ed. A. v. Bogdandy and P. Sonnevend, 111-124. Baden-Baden: Nomos.

Schimmelfennig, F., and U. Sedelmeier. 2004. Governance by Conditionality: EU Rule Transfer to the Candidate Countries of Central and Eastern Europe. Journal of European Public Policy 11 (4): 661-679.

Schlipphak, B., and O. Treib. 2016. Playing the Blame Game on Brussels: The Domestic Political Effects of EU Interventions Against Democratic Backsliding. Journal of European Public Policy 24 (3): 352-365.

Schöpflin, György. 2015. Why Western Liberals Misunderstand Hungary. Politico. https://www.politico.eu/article/western-liberals-have-misunders tood-hungary-migration-geneva-convention/. Accessed 4 May 2020. 
Sedelmeier, Ulrich. 2012. Is Europeanisation Through Conditionality Sustainable? Lock-in of Institutional Change after EU Accession. West European Politics 35 (1): 20-38.

Sólyom, László. 2015. The Rise and Decline of Constitutional Culture in Hungary. In Constitutional Crisis in the European Constitutional Area: Theory, Law and Politics in Hungary and Romania, ed. A. v. Bogdandy and P. Sonnevend, 5-32. Baden-Baden: Nomos.

Szente, Zoltán. 2017. Challenging the Basic Values: The Problems of the Rule of Law in Hungary and the Failure of the European Union to Tackle Them. In The Enforcement of EU Law and Values: Ensuring Member States' Compliance, ed. A. Jakab and D. Kochenov, 456-475. Oxford: Oxford University Press.

Treib, Oliver. 2014. Implementing and complying with EU governance outputs. Living Reviews in European Governance 9.

Vachudova, Milada A. 2005. Europe Undivided: Democracy, Leverage, and Integration After Communism. Oxford: Oxford University Press.

Vachudova, Milada A. 2019. From Competition to Polarization in Central Europe: How Populists Change Party Systems and the European Union. Polity 51 (4): 689-706.

Varga, Judit. 2019. Facts You Always Wanted to Know about Rule of Law but Never Dared to Ask. Euronews. https://www.euronews.com/2019/11/ 19/judit-varga-facts-you-always-wanted-to-know-about-rule-of-law-hungaryview. Accessed 4 May 2020.

Visegrad Group. 2018. V4 Statement on the Future of Europe. http://www.vis egradgroup.eu/v4-statement-on-the-180129. Accessed 4 May 2020.

Waldner, D., and E. Lust. 2018. Unwelcome Change: Coming to Terms with Democratic Backsliding. Annual Review of Political Science 21 (1): 93-113.

Whitehead, Laurence. 1996. The International Dimensions of Democratization. In The international dimensions of democratization: Europe and the Americas, ed. Laurence Whitehead, 3-25. Oxford: Oxford University Press.

Zakaria, Fareed. 1997. The Rise of Illiberal Democracy. Foreign Affairs 76 (6): $22-43$. 
Open Access This chapter is licensed under the terms of the Creative Commons Attribution 4.0 International License (http://creativecommons.org/licenses/ by $/ 4.0 /$ ), which permits use, sharing, adaptation, distribution and reproduction in any medium or format, as long as you give appropriate credit to the original author(s) and the source, provide a link to the Creative Commons license and indicate if changes were made.

The images or other third party material in this chapter are included in the chapter's Creative Commons license, unless indicated otherwise in a credit line to the material. If material is not included in the chapter's Creative Commons license and your intended use is not permitted by statutory regulation or exceeds the permitted use, you will need to obtain permission directly from the copyright holder.

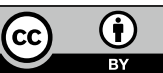

